\title{
ITGAL Gene
}

National Cancer Institute

\section{Source}

National Cancer Institute. IT GAL Gene. NCI Thesaurus. Code C21033.

This gene plays a role in leukocyte intercellular adhesion. 